\title{
Novo Titular de Direito Comercial, Mauro Brandão Lopes
}

\author{
A Redação \\ Saudado pelo Professor Oscar Barreto Filho, foi recebido \\ como Titular da Cadeira de Direito Comercial o Professor \\ Mauro Brandão Lopes, em cerimônia realizada aos 27-6-79. \\ Em seu discurso de posse, o Professor salientou sua \\ preocupação com a Ciência do Direito e com o próprio \\ ensino do Direito, que pode acarretar a formação de maus \\ juristas e maus profissionais, mostrando que a causa dessa \\ situação reside na aceleração da mudança social. \\ Ao lado desse quadro negativo, todavia, o novo Titular \\ exalta a existência de juristas consagrados, que, como legisla- \\ dores lutam contra as leis casuísticas e imperfeitas, como \\ juízes aplicam as leis à luz do interesse público e como \\ advogados vêem a lide como a busca da verdade jurídica.
}

\section{O Novo Titular}

O professor Mauro Brandão Lopes nasceu em Poços de Caldas, Minas Gerais, aos 8 de junho de 1916. E filho do Dr. Juarez do Prado Ferreira Lopes e de D. Maria da Glória Brandão Lopes.

Fez o curso ginasial no Colégio São Luís, em São Paulo, onde se diplomou em 1932. Ingressou então na Faculdade de Direito da Universidade de São Paulo, tendo colado grau aos 18 de janeiro de 1938.

Cursou a Universidade de Yale, nos Estados Unidos da América do Norte, no período de março de 1946 a junho de 1949, e obteve o título de Master of Arts em Ciência Política e, na Faculdade de Direito de Yale, fez cursos de verão sobre Labor Law and Arbitration, ministrado por J. Frey e 0 . Fraenkel, e sobre Legal Principles of Competitive Economics, por Abe Fortas e Thurman Arnold.

O professor Mauro Brandão Lopes iniciou sua carreira de docente na Escola de Sociologia e Política de São Paulo, instituto anexo à Universidade de São Paulo, onde lecionou no período de 1949 a 1956.

Foi também professor na Escola de Administração de Empresas de São Paulo, da Fundação Getúlio Vargas, onde lecionou Sociologia Industrial, de 1958 a .1961, e Direito Comercial, de 1961 a 1970. 
Exerceu ainda o cargo de regente da cadeira de Direito Comercial da Universidade Mackenzie, no ano letivo de 1962, substituindo o Professor George Marcondes Coelho de Souza.

Foi professor livre docente de Direito Comercial, tendo ingressado nesta Faculdade de Direito em 23 de março de 1961, como assistente da cadeira, e a 11 de fevereiro de 1965 passa a livre docente e regente da referida cadeira, cargo que exerceu até 1971. O curso diurno foi por ele regido de 1969 a 1971.

Substituiu o Professor Sylvio Marcondes durante seu afastamento para elaboração do Código Civil, inclusive junto à Congregação. E, em 1976 passou a professor adjunto do Departamento de Direito Comercial da Faculdade de Direito da Universidade de São Paulo.

membro do Instituto de Direito Social, do Instituto Brasileiro de Direito Tributário, do Instituto dos Advogados de São Paulo.

\section{Cursos}

O Professor Mauro Brandão Lopes, sempre voltado à cultura da Ciência, ministrou diversos cursos e conferências, tanto nesta Faculdade como em outras Universidades do país e do exterior.

Na Escola de Sociologia e Política de São Paulo, lecionou no curso sobre doutrinas e ideologias políticas do Ocidente, instituições políticas democráticas e partidos políticos.

$\mathrm{Na}$ Escola de Administração de Empresas de São Paulo, na cadeira de Sociologia Industrial, ministrou cursos sobre o trabalho na empresa e sobre empresa e sociedade; na cadeira de Direito Comercial, abordou os seguintes assuntos: disciplina legal da atividade empresarial e títulos de crédito.

Em nossa Faculdade, além dos cursos normais de graduação, ministrou as seguintes disciplinas, a nível de pós-graduação: Sociedades Mercantis em Direito Comparado, Títulos de Crédito em Direito Comparado, Falência e Títulos Societários no Direito Comercial Comparado.

Além dessas atividades didáticas, o Professor Mauro pronunciou uma série de conferências, sobre os mais variados assuntos, aqui no Brasil e em Universidades no exterior:

- "A estrutura política da Rússia Soviética", no Instituto Rio Branco, do Ministério das Relações Exteriores. 


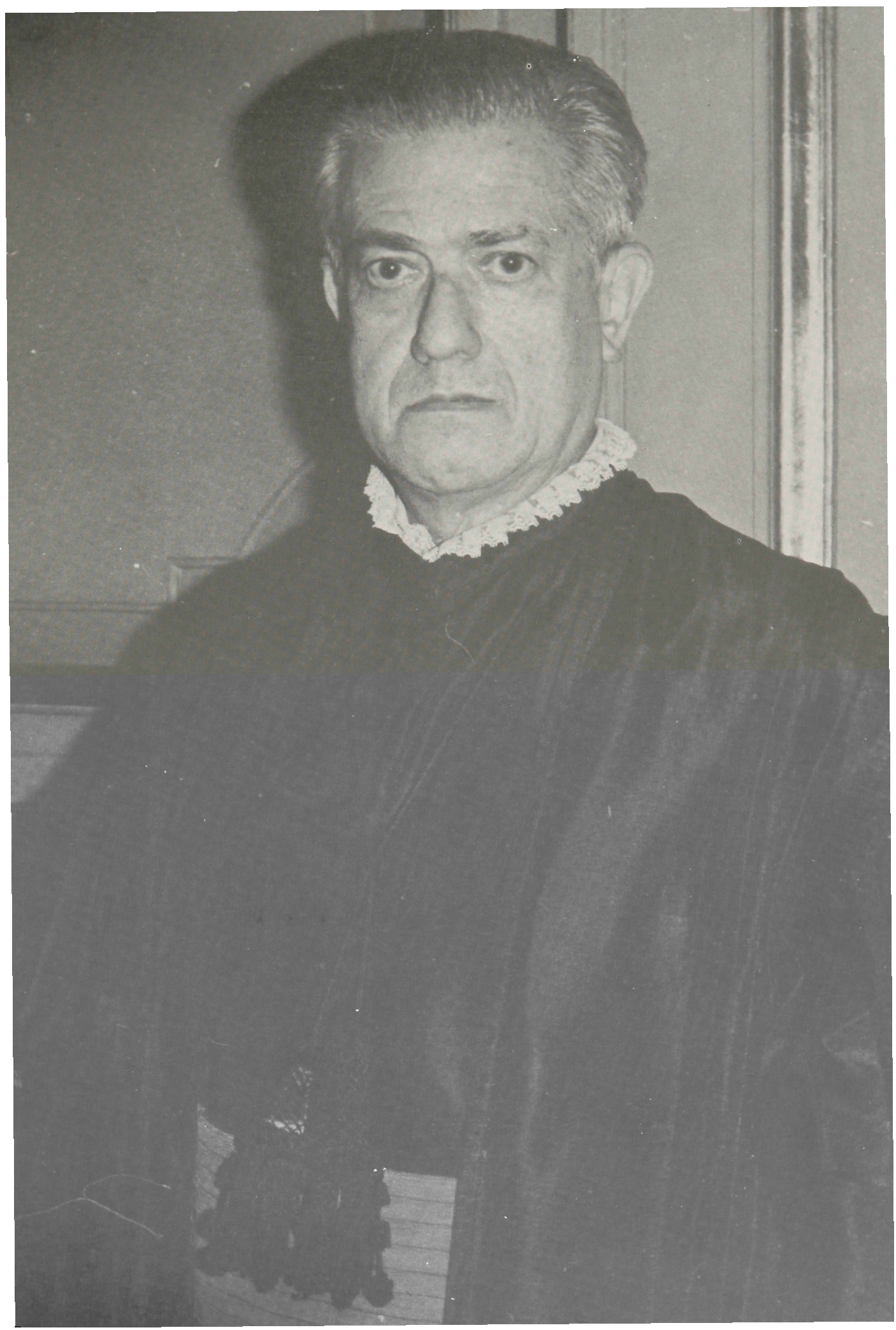


Professor Titular de Direito Comercial,

Dr. Mauro Brandão Lopes. 
- "Partido e Estado na União Soviética", na Escola Superior de Guerra, em 1952.

- "O funcionamento das Instituições Democráticas", na Associação Comercial de São Paulo, em 1952. em 1955 .

- "Partidos políticos", na Universidade de Minas Gerais,

"A grande depressão e seus reflexos políticos" - Faculdade de Ciências Econômicas da PUC de Campinas, em 1959.

- "O processo político nos Estados democráticos e nos Estados totalitários, na Faculdade de Higiene e Saúde Pública da USP em 1960.

— "Sistema eleitoral e democracia", na Escola Paulista de Medicina, em 1963.

- "Bird's eye view of Brazilian political history", na Universidade de Georgetown, em Washington D.C., em 1966.

- "Letra de câmbio e nota promissória : emissão e circulação", na Associação dos Bancos do Estado de São Paulo, em 1972.

- "As inovaçóes sobre a letra de câmbio e a nota promissória, na Lei Uniforme de Genebra", na Associação dos Advogados de São Paulo, em 1973.

- "As sociedades não personificadas - sociedade em comum e sociedade em conta de participação", na Câmara Municipal de São Paulo, em 1974.

- "Os títulos de crédito" na Associação dos Advogados de São Paulo, em 1975, e projeto do Código Civil, no mesmo local.

- "Títulos de crédito na sistemática do mercado de capitais", no curso de especialização em Direito Comercial, da PUC de São Paulo, em 1975.

- "As funções do agente emissor de certificados" na Sociedade dos Usuários de Computadores e Equipamentos subsidiários, em 1976.

— "Os novos títulos de emissão das sociedades anônimas", no Instituto dos Advogados de São Paulo, em 1977.

- “Títulos de créditos novos na Lei $6.404 / 76 "$, no Centro de Estudos de Extensão Universitária.

- "Os valores mobiliários de emissão de companhias na Lei 6.404/76", no Departamento de Direito Comercial, em comemoração ao Sesquicentenário da Fundação dos Cursos Jurídicos no Brasil. 
- "As ações e os demais títulos de emissão das sociedades anônimas" nas Faculdades Metropolitanas Unidas.

- "Partnerships, companies and corporations in Brazil", na Câmara Americana de Comércio.

- "A empresa pública no Brasil e nos Estados Unidos", na Universidade de Brasília, em 1976.

- "Coligações, consórcios e grupos de sociedades" no seminário de Lei de S.A. promovido pelo Unibanco, em 1977.

- "Aquisição de cotas sociais pela sociedade", em seminário organização pelo Instituto Brasileiro de Direito Comercial e Associação Comercial de São Paulo, em 1977.

- "A responsabilidade de diretores de instituições financeiras nas Leis 6.024/74 e 6.404/76, na Universidade de Brasília, em 1977.

O Professor Mauro B. Lopes, devido à sua formação cultural, sempre foi aberto aos problemas dos estudantes e portanto, muito chegado a seus alunos para orientação ao estudo.

De início, foi encarregado das aulas práticas e isso possibilitou grande entrosamento na discussão dos problemas levantados em classe. Nas aulas teóricas mantém o mesmo relacionamento com os estudantes, conseguindo com isso grande rendimento escolar.

Quando da reforma universitária e conseqüente criação dos Departamentos, o Prof. Mauro desempenhou tarefas relativas à contratação de professores, elaboração de programas, provas de reavaliação, etc. Foi subchefe do Departamento de Direito Comercial desde 1974; orientou alunos de graduação e pós-graduação, teses de mestrado e foi membro das Comissões examinadoras nas defesas de tese de mestrado, de doutoramento e exames de qualificação de bacharéis, pertencentes aos diversos Departamentos desta Faculdade de Direito e também da Pontifícia Universidade Católica de São Paulo.

\section{Atividades Profissionais}

O Professor Mauro foi juiz do Tribunal de Impostos e Taxas da Secretaria da Fazenda do Estado de São Paulo, nos períodos de fevereiro de 1942 a fevereiro de 1946, e de julho de 1949 a dezembro de 1961.

Exerceu o cargo de membro do Conselho Técnico da Diretoria da Associação Comercial de São Paulo e também o 
de Conselheiro do Instituto de Sociologia e Política da Federação do Comércio do Estado de São Paulo, até 1958.

Foi assessor jurídico da Federação do Comércio do Estado de São Paulo e do Sindicato dos Lojistas do Comércio de São Paulo.

É advogado militante no foro de São Paulo desde 1938, e presta assessoria contínua a empresas dos setores de publicidade, reflorestamento, mineração e a holdings do setor financeiro.

É membro do Conselho Editorial da Revista de Direito Mercantil, Industrial, Econômico e Financeiro.

o Professor Mauro elaborou diversos pareceres sobre matérias de sua especialidade, tanto para informação de processos como para resposta a consultas a ele formuladas.

\section{Produção científica}

A contribuição científica do Professor Mauro Brandão Lopes é muito importante, no campo do ảireito comercial e em Política Social. Suas obras são publicadas pelas mais renomadas editoras e seus artigos figuram nas revistas especializadas.

\section{Artigos}

- Ensaio sobre a atual situação política do Brasil. In: Digesto Econômico, 10 (115), 1954.

- Facções políticas, máquinas eleitorais e partidos políticos. In: Digesto Econômico, 10 (118), 1954.

- Ensaio sobre as antinomias existentes no pensamento político moderno. In: Serviço Social 14(71), 1954.

- Absolutismo e democracia na Inglaterra do século XVII: Hobbes, Locke e a Revolução de 1688. In: Introdução ao Pensamento Político, São Paulo, Federação do Comércio do Estado, 1955.

- Consideraçōes sobre o eleitorado democrático. In: Correio Paulistano, de $5,8,10$ e 12 de junho de 1955 .

- Sistema eleitoral e democracia. In: Correio Paulistano, 22 e 24 de junho de 1955.

- O multipartidarismo e o processo legislativo brasileiro. In: Correio Paulistano, 26, 28, 30 e 31 de julho de 1955.

- Sistema partidário e maioria absoluta. Correio Paulistano, 30-10-1955.

- A incompreensão do regime político brasileiro. Correio Paulistano, 17-11-1955.

- Mill e a posição liberal. Correio Paulistano, 27-11-1955.

- Requisitos de um sistema eleitoral sadio. Correio Paulistano, 7 e 11-12-1955.

- Influência da Constituição sobre os partidos políticos norte-americanos. Correio Paulistano, 5-1-1956. 
- A estrutura político-partidária e a segurança nacional. In: Estudo Sócio-político da Vida Nacional. São Paulo, Instituto de Sociologia e Política da Federação do Comércio do Estado, 1958.

- Cambial. Ineficácia de cláusula ou pacto de vencimento antecipado, em separado. Cláusula incompatível com a natureza do título. In: Revista de Direito Mercantil, Industrial, Economico e Financeiro, 10(3), nova série, 1971.

- A sociedade em comum: inovação do Anteprojeto de Código Civil. In: Revista de Direito Mercantil, Industrial, Econômico e Financeiro, $13(15 / 16)$ nova série, 1974.

- Natureza jurídica do 'leasing'. In: Revista de Direito Mercantil, Industrial, Econômico e Financeiro, 13(14), 1974.

- Endosso-mandato e requerimento de falência: In: Revista de Direito Mercantil, Industrial, Econômico e Financeiro, 14(18), nova série, 1974.

- O direito de preferência do acionista e a evolução da sociedade anônima no Brasil. In: Revista de Direito Mercantil Industrial, Econômico e Financeiro, 14(19), nova série, 1975.

- Os agentes emissores de certificados, os certificados de depósito de valores mobiliários e a custódia de ações fungíveis. In: Balancete Mensal: Revista da Associação dos Bancos no Estado de São Paulo, 3 (31), jul. 1976.

- Ainda a custódia de ações fungíveis. In: Balancete Mensal: Revista da Associação dos Bancos do Estado de São Paulo, s(32), ago. 1976.

- Incorporação de Reservas e Distribuição de ações bonificadas. In: Diário do Comércio \& Indústria de 9,11, 16, 18 de julho de 1977.

- A Responsabilidade dos Administradores de Sociedades Anônimas. In: Diario do Comércio \& Indústria, 20-12-77.

Livros:

- Ensaio sobre a conta de participação no direito brasileiro. São Paulo, Revista dos Tribunais, 1964.

- A natureza e o regime legal do cheque bancário. São Paulo, Revista dos Tribunais, 1978.

- Cambial em moeda estrangeira. São Paulo, Revista dos Tribunais, 1978.

- S.A. - Títulos e contratos novos. São Paulo, Revista dos Tribunais, 1978.

Além dessas obras, o Professor Mauro B. Lopes ainda executou trabalhos para a Comissão elaboradora do Anteprojeto do Código Civil, e efetuou tradução de obras especializadas de autores estrangeiros, principalmente norte-americanos.

\section{Posse}

No dia 27 de junho de 1979, às 20,30 horas, reuniu-se a Congregação dos professores da Faculdade de Direito, no Salão 
Nobre, para receber o novo titular de Direito Comercial, o Professor Mauro Brandão Lopes.

O diretor da Faculdade, Professor Antônio Chaves, presidiu a sessão, ao lado da vice-diretora, Doutora Nair Lemos Gonçalves e da Secretária da Faculdade, Doutora Drinadir Coelho, e estando presentes numerosos professores, amigos e alunos do novo Titular.

A saudação foi feita pelo Professor Oscar Barreto Filho, que, em brilhante exposição, salientou as qualidades do Professor Mauro Brandão Lopes como docente, sempre preocupado com o bom rendimento de seus alunos; como profissional, exercendo funções variadas, e como colega e amigo exemplar, além de cultor da ciência e do saber.

A seguir, o Professor Mauro agradeceu a homenagem que lhe foi prestada, prometendo lutar sempre pela dignificação do ensino e da cultura jurídica, e termina agradecendo aos mestres desta Escola o exemplo que sempre representaram para ele, especialmente o Professor Oscar Barreto Filho, que ora o saúda.

\section{Saudação do Professor Oscar Barreto Filho}

Bem merece Mauro Brandão Lopes esta festa de inteligência e de amizade, em que se reúnem seus colegas e alunos para homenageá-lo pela ascensão ao grau máximo da carreira universitária.

Cedo madrugou para as coisas do espírito, guiado pelas mãos experientes do pai, advogado e humanista que muito apreciava a literatura portuguesa, possuidor que era de uma valiosa camiliana. Não the faltou também, por influência materna, a iniciação musical, no estudo do piano.

Terminados os estudos básicos, cursou Mauro, sucessivamente, a velha Academia do Largo de São Francisco, formando-se com a turma de 1937, e a Escola Livre de Sociologia e Política, hoje integrada na Universidade de São Paulo.

Bacharel formado, além da advocacia militante no foro de São Paulo, desde agosto de 1938, prestou continuamente assessoria jurídica a várias empresas e entidades de classe do comércio. Em largo período, de fevereiro de 1942 a dezembro de 1961, desempenhou a função de Juiz do Tribunal de Impostos e Taxas da Secretaria da Fazenda do Estado de São Paulo, com a proficiência atestada pelas várias reconduções que obteve naquela função. 
Contemplado com bolsa de estudo, cursou o nosso homenageado a Universidade de Yale, Estados Unidos da América do Norte, no período de março de 1946 a junho de 1949. Com esforço e dedicação, obteve o título de Master of Arts em Ciência Política e, ainda, na Faculdade de Direito de Yale, fez cursos de verão sobre Labor Law and Arbitration, ministrado por J. Frey e O. Fraenkel e sobre Legal Principles of Competitive Economics, por Abe Fortas e Thurman Arnold.

Foram estes anos, passados na atmosfera agradável e sob o céu azul de New Haven, estudando e passeando nos relvados das campinas da velha Universidade, os melhores e mais saudosos de sua vida, segundo me confidenciou o próprio Mauro. A despreocupação e à esperança da mocidade, ainda acresceu a companhia querida da esposa Maria Júlia e do filhinho Ricardo.

Deve-se à vivência na secular escola de Elihu Yale o interesse sempre renovado de Mauro pelas coisas da arte; não se esqueça que, a par das escolas profissionais, na instituição da Nova Inglaterra também existem departamentos de teologia, filosofia, belas artes, música, drama e até um teatro universitário. E, naturalmente, tudo isso influenciou o moço sensível e talentoso para a integração de sua personalidade.

Encetou Mauro Brandão Lopes suas atividades didáticas como professor de Ciência Política, na Escola de Sociologia e Política de São Paulo (onde lecionou de 1949 a 1956), e de Sociologia Industrial, na Escola de Administração de Empresas da Fundação Getúlio Vargas (de 1958 a 1961), na qual também foi professor de Direito Comercial (de 1961 a 1970).

Ingressou em nossa Faculdade de Direito, como assistente, em 1961, passou a Livre-Docente de Direito Comercial em 1965, substituindo por largo tempo o Professor Sylvio Marcondes na regência da cadeira, inclusive na Congregação e no Curso de Pós-Graduação durante o seu afastamento para elaborar o Anteprojeto de Código Civil. Em 1976, passou a Professor Adjunto.

Participando sempre de programas de extensão universitária, proferiu cursos e conferências na Faculdade de Direito da Universidade Mackenzie, no Instituto Rio Branco do Ministério das Relações Exteriores (1949), na Escola Superior de Guerra (1952), na Federação do Comércio do Estado de São Paulo (1954), na Universidade de Minas Gerais (1955), na Universidade Católica de Campinas (1959), na Associação dos Bancos no Estado de São Paulo (1972) e na Associação dos Advogados de São Paulo (1973) 
Convidado pelo Governo norte-americano, pronunciou conferência sobre a história política do Brasil na Universidade de Georgetown, em Washington D.C. (1966).

Desde o início de sua atividade de formação e orientação de alunos, ministrando aulas práticas como assistente, o Professor Mauro sempre manteve estreito contato com os estudantes.

Inspirado pelo que viu nos Estados Unidos, trouxe para a nossa Academia um relacionamento menos formal do que o tradicionalmente existente entre estudantes e professores, de modo a propiciar intercâmbio mais freqüente de idéias e de experiências.

Dotado de fácil comunicação, consegue o Professor Mauro desempenhar sem esforço sua tarefa, e reconhecem seus alunos de sucessivas turmas que em verdade tem ele o dom de ensinar.

Igual performance vem desempenhando o nosso mestre na regência dos cursos de pós-graduação de que foi incumbido, a partir de 1973, nas áreas de Sociedades Mercantis, Títulos de Crédito e Falências em Direito Comparado. Por ocasião da promulgação da nova lei de sociedades anônimas, proferiu também conferências a respeito de vários aspectos atuais do novo estatuto das companhias.

Importante é a produção científica do Professor Mauro Brandão Lopes, não somente no campo do Direito, como no da Ciência Política, ramo a que primeiramente se dedicou.

Numerosos artigos seus, a respeito de história do pensamento político, teoria política e problemas políticos brasileiros foram estampados na imprensa diária e também em revistas especializadas, entre 1954 e 1958, além de traduções das obras de McIver, $O$ Estado, e de excertos de autores diversos, incluídos em Estudos de Ecologia Humana e Estudos de Organização Social, sob a direção do Prof. Donald Pierson (1948).

No tocante ao Direito, além de sem-número de artigos, estudos e ensaios, a partir de 1964 publicou os seguintes livros: Ensaio sobre a conta de participação no direito brasileiro, A natureza e o regime legal do cheque bancário, Cambial em moeda estrangeira, Sociedade anônima: títulos e contratos novos, $A$ disciplina brasileira de cisão no direito societário.

Colaborador constante da Revista de Direito Mercantil, editada sob os auspícios do nosso Instituto Brasileiro de Direito Comercial Comparado Tullio Ascarelli, tem versado de preferência as inovações introduzidas em nosso direito empresarial 
por leis recentes, tais como o contrato de "leasing", os novos títulos das sociedades anônimas, a custódia de ações fungíveis.

t também membro do Instituto de Direito Social, do Instituto Brasileiro de Direito Tributário e do Instituto dos Advogados de São Paulo.

Prova de reconhecimento do mérito do nosso homenageado de hoje está no convite que recebeu do eminente Professor Miguel Reale, a fim de colaborar na redação final de parte relativa aos títulos de crédito, no Anteprojeto de Código Civil, ora em tramitação no Congresso Nacional.

A contribuição científica de maior relevância do Professor Mauro Brandão Lopes é, sem dúvida, representada pela sua monografia a respeito da disciplina da cisão societária, oferecida para concurso à cátedra de Direito Comercial.

Nesse livro, o autor adota uma posição culturalista, pois, além das normas operacionais que regulam o instituto da cisão, investiga e apresenta os fundamentos dogmáticos do tema, indagando os princípios que informam e legitimam, no plano axiológico, a disciplina legal.

0 autor situa-se numa perspectiva abrangente, centrada, abarcando numa visão ampla e integrada aspectos do direito societário, patrimonial, obrigacional, falimentar e processual.

Detém-se na análise dos institutos, sem limitar-se à mera exposição dos ordenamentos legislativos alienígenas, perquirindo acerca dos fundamentos doutrinários do instituto.

Revela ainda o autor sua preocupação metodológica na parte introdutória, ao discorrer sobre os conceitos de "construção jurídica" e de "integração" do texto legal. Ao apresentar o plano de trabalho, o autor evidencia o maior cuidado na elaboração do tema, de modo a apreciá-lo no seu todo, como estrutura "orgânica" e não decomposto em seus aspectos específicos, cada um isolado dos demais.

A importante contribuição científica do autor, todavia, reside no afastamento da inadequada visão que pretende caracterizar a cisão como instrumento de desconcentração societária, ou, ao revés, de concentração societária.

0 autor refoge desses conceitos sediços para, com felicidade, situar o instituto da cisão a partir da teoria do patrimônio, que se explica essencialmente como um fenômeno de fragmentação patrimonial, dando origem a patrimônios separados. 
Partindo do conceito de patrimônio separado, considera o autor a nova categoria a que a lei brasileira prende a cisão: a "parcela de patrimônio", que constitui o núcleo central da cisão.

Com apoio na doutrina comparada, segundo a qual o fragmento de cisão é necessariamente um active business, o autor delineia nova síntese, com a projeção do instituto da cisão na teoria da empresa, desvinculada da pessoa do empresário. Pode-se discordar da tese, porém não se pode negar a consistência da argumentação expendida.

Somente quem conhece na intimidade o Professor Mauro, pode avaliar devidamente a sua personalidade rica de conteúdo humano, de inteireza moral e de sensibilidade artística, que se expressam nos menores atos.

No meio da cidade grande, apertado entre os edifícios de apartamentos, logrou Mauro construir o seu refúgio familiar, onde, na calma e quietude do estúdio situado no sótão, executa as suas atividades de professor e de advogado, ouvindo os acordes de selecionadas músicas clássicas. Nos vagares de sua labuta, encontra ainda tempo para ler prosa e poesia.

$\mathrm{Na}$ sua postura de homem tranqüilo, cumpre com exatidão os deveres de pai de família, nunca olvidando as tarefas profissionais, com a serena convicção de que o homem foi feito para o trabalho. Entende, conforme o ensinamento do Livro Santo, que do trabalho derivam as maiores alegrias e satisfações que se pode ter na vida terrena, pois somente ao homem que sabe cultivar e guardar, reserva o Senhor Deus o paraíso das delícias (Gênesis, 2, 15).

Pelo seu esforço, pela sua pertinácia, pela sua dedicação, pela sua seriedade de propósitos, o Professor Mauro Brandão Lopes está à altura das tradições da cátedra que, no passado, foi honrada pelas figuras exponenciais de Frederico Vergueiro Steidel, Waldemar Ferreira e Sylvio Marcondes Machado, numes tutelares do Direito Comercial brasileiro. Em suas mãos, tenho a certeza de que a bandeira não cairá.

Tenho dito.

\section{Agradecimento de Mauro Brandão Lopes}

No correr dos anos, desde que me convidou para assistente, - Professor Sylvio Marcondes, estive neste salão em posses solenes de vários professores; e surpreendeu-me com freqüência, por inesperado, o tema central escolhido. De nenhum 
deles indaguei a razão da escolha, às vezes por acanhamento, diante de tratamento distante, embora sempre cortês, deles recebido, outras vezes sem explicação razoável, porque tinham comigo relacionamento cordial ou se tinham mesmo tornado meus amigos. Só se desfez o mistério ao me encontrar na contingência, e não havia fugir dela sem descortesia, de lhes falar com seriedade e sem tecnicismos em tão especial momento. Como hoje comigo acontece, eles também sentiram a necessidade de dar forma explícita à preocupação básica sobre a própria ciência do direito ou o seu ensino, ou ambos os temas, porque são indissociáveis.

Como é natural, professores de direito devem se preocupar com sua ciência; mas a preocupação de muitos deles, como hoje a minha, ia além do cuidado do estudioso com a sua disciplina. Não se trata do domínio do artífice sobre o seu material, nem da elaboração de formas e métodos novos; trata-se do crescente temor de rejeição do próprio produto. Se me permitem mudar a imagem, sente-se no Brasil que a árvore do direito tradicional não mais dá bons frutos. Nem vale o conselho de não confundir o direito pátrio com o conjunto amorfo (o não-sistema) das leis brasileiras: nas leis está o direito, e a má qualidade daquelas demonstra que coisa grave está ocorrendo com este. E de outro lado não se pode ensinar bem um direito mau.

Deixem-me abandonar por um instante as imagens, sempre necessárias mas sempre más, e tome direta responsabilidade por esta posição. Estou é mesmo afirmando que o direito brasileiro não mais constitui um sistema, não mais tem o rigor conceitual e a congruência interna, necessários para sua aplicação adequada na feitura das leis e no ensino dos jovens. $\mathrm{E}$ estas duas características do não-sistema brasileiro levam a leis más; as leis más nele introduzem conceitos ainda mais defeituosos em mais acentuada incongruência, e estes levam a leis ainda piores, em círculo vicioso difícil de romper.

No ensino, a imprecisão de conceitos e a incongruência interna da massa amorfa das leis brasileiras, aliadas ao despreparo dos alunos, produzem maus juristas e os produzem em grande quantidade. Ora, os maus juristas são maus legisladores, e enxertam nas leis a sua má formação conceitual; os maus juristas são maus juízes, e traduzem leis más em pior jurisprudência; e, ainda mais sério, os maus juristas são maus advogados, e fazem de sua profissão busca contínua de meios e modos, não propriamente de burlar os objetivos de leis boas, mas de usar as más contra adversários dedicados à mesma 
tarefa, fazendo lutas desleais das lides forenses, em que todas as manobras não só são possíveis, como são mesmo esperadas, e muitas vezes elogiadas.

Este quadro é parcial, sem dúvida, e por isso incorreto, e exige a nota qualificadora das muitas exceções existentes, os juristas vencedores do meio educacional de que emergem. Como legisladores lutam eles para deter a avalanche de leis casuísticas e imperfeitas; como juízes aplicam leis ruins à luz de interesse social arduamente pesquisado, fazendo saneadora obra legislativa no nível do judiciário; como advogados vêem a lide como busca da verdade jurídica no esforço conjugado de partes, advogados, e magistrados; e como professores lidam pacientes com alunos despreparados e rebeldes ao estudo.

0 quadro, contudo, é predominantemente negativo, e resulta no desprezo generalizado pelo direito, com suas nefastas conseqüências - a improvisação no embuste, inculcando muitas vezes arbítrio por lei, e a adoção indiscriminada de institutos estrangeiros, por vezes ultrapassados na própria sociedade em que surgiram e aqui apresentados como as mais avançadas das técnicas existentes, as duas levando a altíssima mortalidade legislativa, com leis que se reformam umas às outras e com transplantes sucessivos de rejeição imediata.

Até aqui descrevo falhas e não indico consertos. Mas como o bom médico, diante de enfermidade que não sabe prevenir nem curar, por isso mesmo e com maior afinco busca prevenção e cura, assim também o jurista, diante de males que diretamente afligem o seu ofício, não se pode eximir de pesquisa das causas. Ora, a causa genérica dos desconsertos do mundo moderno vem sendo apontada desde o início do século por filósofos e sociólogos como estando na aceleração da mudança social; e o diagnóstico é uniformemente o mesmo, centrando-se sempre no mesmo fenômeno, a industrialização desordenada. $\mathrm{E}$ todos os estudiosos, ao versar o tema, prendem esse movimento de aceleração da mudança, em última análise, à revolução industrial inglesa, as que a sucederam principalmente nos Estados Unidos, no Japão, e na Alemanha ocidental, e por fim à atual revolução tecnológica global.

Desta revolução tecnológica, de tão crucial relevância para a humanidade, nota Kenneth Boulding, economista e pensador social eminente, escrevendo em 1966, que o mundo atual é tão diferente do mundo em que ele mesmo nasceu como do mundo de Júlio César, e situa a própria geração no centro da história econômica do homem. Na verdade, o desejo de verificar esta assertiva de Boulding levou Toffler, ao citá-la 
no seu Choque do Futuro, a dividir os últimos 50.000 anos da existência do homem em 800 gerações de 62 anos cada uma, ressaltando então que 650 delas foram vividas em cavernas, que só durante as últimas 70 puderam os homens comunicar-se por escrito, só durante as últimas 6 fizeram uso da página impressa, só durante as últimas 4 souberam medir o tempo com razoável exatidão, e que os bens materiais de uso diário nas grandes nações do ocidente, na sua esmagadora maioria, só se produziram na última geração. Neste sentido, nesta geração, a última das oitocentas, está a verdadeira linha divisória da história econômica da humanidade, embora evidentemente não a espiritual. Como se vê, o critério de Boulding e Toffler, para separar em duas metades a história econômica, é o critério da rapidez da mudança, sob o impacto da tecnologia moderna.

Nesta nova era, a segunda metade da história, a agricultura não mais domina a vida do homem, como se vê do exemplo mais notável neste setor, os Estados Unidos, onde as áreas de cultura alimentam duzentos milhões de americanos, nelas se empregando menos de $6 \%$ da população; e para esta situação caminha toda a Terra, porque nações de estrutura social agrária, com industrialização rudimentar, são nações dominadas. $\mathrm{O}$ homem moderno vive na cidade, e a cidade, produto do processo de industrialização, que desde o início gera mudança acelerada, é desagregadora e destruidora de valores na direta proporção de seu tamanho.

$\mathrm{E}$ neste movimento desagregador insere-se um outro, de direta incidência no ensino do direito; é o movimento que teve o caráter inicial de rebelião de jovens, em seus inúmeros matizes, mas se firmou, como parte de movimento mais amplo, com a presença de diferente estrutura mental. O novo fenômeno é indubitável, e os seus traços básicos tiram-se da leitura de Marshall McLuhan em livros sucessivos: ao lado do modelo da página impressa, outro existe, gestaltiano, de apreensão instantânea de situações totais.

A primeira mentalidade, assim como a página impressa, é de caráter linear e discursivo, determinando o pensamento consubstanciado em encadeamento lógico, o instrumento essencial do jurista, e é de aceitação imediata; a segunda é de difícil caracterização, porque ao reduzi-la a pensamento lógico nega-se a sua essência, restando de tal sorte o caminho da descrição fragmentada e da vivência direta. Ora, esta nova mentalidade distingue-se da primeira pela rejeição do conceito lógico: usam-no os seus representantes como homens que, em terra 
estranha, aprendem, dos rudimentos da língua nativa, apenas o estritamente necessário para a comunicação indispensável. Entre eles mesmos, usam de comunicação não-conceitual, como a música, o gesto, a imagem, a dança. Por tudo isto é possível afirmar como conflito fundamental a competição entre o jornal de molde tradicional e o jornal de som e imagem, entre o livro e a novela de TV, entre a música de ritmo total e a música temática, de estrutura complexa, chamada de erudita quase como repúdio à primeira.

E não se trata, como patente da leitura de McLuhan, de maneirismos de contestadores; trata-se de características de duas gerações pelo menos, a primeira delas atuante no mundo econômico, em competição com a anterior, que logo suplantará só para ceder o lugar à seguinte, ainda mais inovadora. Este quadro seria angustiante, e trágico para a disciplina jurídica, se as gerações fossem monolíticas; felizmente não são. Os conquistadores, quando ocupam território sem eliminar os vencidos, acabam assimilados; mas, de outro lado, as levas sucessivas de conquistadores introduzem na sociedade vencida, e ao mesmo tempo vitoriosa, traços culturais perturbadores que sempre a transformam radicalmente.

Também a sociedade brasileira está em violenta transformação, com a conseqüente inexatidão conceitual do direito pátrio e sua incongruência interna; e à imprescindível tarefa de renovação é essencial a continuidade das gerações de bons juristas. Assim, daquela tarefa é parte fundamental a renovação do ensino jurídico; as duas tarefas fundem-se numa única. O grande desafio aí está, mas dos grandes desafios, adequadamente enfrentados, como pretende Toynbee em outro e mais amplo contexto, surgem as grandes realizações. $E$ de qualquer modo a alternativa parece ser a vitória do não-direito, já claramente em sub-reptícia formação, prenunciando período de caos social, pois as sociedades sãs dependem de sólidas estruturas jurídicas; sem elas não há boa administração da justiça, e sem esta não se pode sequer falar de comunidade política, mas só de dominação de facções em insuportável alternação.

No passado, os remédios a males sociais encontraram-se com freqüência em termos locais; e não seria a primeira vez que uma nova ordem social viesse a surgir como resultado de resistência localizada forçando compromisso vital. Mas examinemos um precedente histórico, não muito lembrado entre nós, sobre resistência a mudança indesejada, e duas tentativas modernas de disciplinar a transformação de sistemas jurídicos, 
para só depois considerar o igualmente grave problema do ensino jurídico.

O precedente histórico situa-se no início do século XVII. Refiro-me à resistência liderada por Edward Coke, então o mais alto magistrado do reino inglês, contra as pretensões de James I de ampliar as suas prerrogativas. Desde o seu início, é bom lembrar, o movimento absolutista transcendia fronteiras; e embora não-coincidentes no tempo as etapas nacionais, foi irresistível nos vários países do ocidente europeu, dominando-o por mais de dois séculos e marcando-o profundamente, com exceção da Inglaterra; de outro lado, lembrem ainda, o escocês James I, ao subir ao trono inglês, vinha de firme tradição de apoio francês, e trazia consigo o gosto pelo poder absoluto. Não vou aqui rememorar a história inglesa do período; quero apenas indicar a arma que contra James I usou Edward Coke, a concepção medieval do poder supremo na comunidade, contrapondo-a à pretensão monárquica do poder como prerrogativa do rei.

Coke foi assim o grande campeão do common law, o conjunto orgânico de normas formado nos cinco séculos anteriores, impondo-se como a lei fundamental do reino, considerada como a corporificação da própria razão, declarada pelos juízes, mas não por eles elaborada, com o parlamento no papel de árbitro último nessa declaração. Nessa lei fundamental, para Coke e os juristas e pensadores que o precederam, encontrava o rei bem definidos os seus direitos e deveres, como também os encontravam o parlamento e cada cidadão em toda a escala social. E nessa linha vitoriosa consolidou-se afinal na Inglaterra a teoria da supremacia do parlamento, enquanto, nos demais países do oeste europeu, a prerrogativa última do soberano, i.e., do detentor do poder executivo, se transferia para o Estad.o. E na Inglaterra, sob a idéia central de que o soberano inglês é o parlamento, desenvolveu-se a luta política subseqüente, até a conquista do pleno sufrágio popular e o alijamento dos reis, e de quaisquer outros intrusos, do governo da coisa pública.

No conflito inglês do século XVII, do qual saiu vitoriosa a concepção medieval de que o direito reside na própria nação, está assim a origem da diferença básica entre dois conceitos de soberania - o surgido na Inglaterra, i.e., o conceito de soberania popular no parlamento, e o mais difuso, e muito mais perigoso, de soberania do Estado. Mesmo que a referência usual se faça hoje indiscriminadamente à soberania nacional, na Grã-Bretanha moderna ela reside no parlamento 
como órgão representativo, enquanto nas demais nações ela reside no Estado, seja qual for a sua forma de governo, com todas as possíveis nuances de maior ou menor autoridade. Ora, na luta, de que saíram vencedores Coke e a magistratura britânica, a arma ideológica usada foi exatamente a concepção visada pelos absolutistas, a idéia do direito como existente na própria nação, e dela tirada pelo jurista.

Passo em seguida às duas tentativas modernas de disciplinar a transformação de sistemas jurídicos; e deixo sem discussão, por evidente, o fato de ser esse disciplinamento indispensável, e mais importante do que planos nacionais de desenvolvimento, porque a alternativa não é estagnação econômica mas o caos social.

Das duas tentativas, a primeira está no movimento liderado pela American Bar Association, que é entidade de direito privado, sem conexões governamentais exceto de prestígio. $\mathrm{Na}$ sua National Conference of Commissioners on Uniform State Laws, enfrentou ela problema grave, o de influir nas legislaturas estaduais a fim de uniformizar leis divergentes; e a divergência constituía então verdadeiro escândalo, notadamente no campo do direito comercial, porque o comércio interestadual e as práticas financeiras, sem cuidar de fronteiras, se contrapunham frontalmente às diversas legislações estaduais. Para isso a Associação, por meio de seu órgão especializado, preparou, desde a sua fundação em 1878, leis-modelos, até agora mais de 25 delas, além de leis específicas inúmeras. Das leis-modelos, mais de uma dezena foi adotada pela maioria dos Estados, tendo a mais notável delas, a Model Business Corporation Act, em revisão posterior, tido influência inegável nas nações do oeste europeu, e recentemente no Brasil como se pode notar na nossa última lei sobre sociedades anônimas.

Acentuo neste movimento aspecto notável para o meu tema, a sua influência estabilizadora na transformação de institutos jurídicos; e não tenho mesmo receio de afirmar são juristas os homens que evitam o caos norte-americano. A sociedade norte-americana neste século apresenta, de todas as outras, a mais radical mudança; na verdade, dela, e não da União Soviética ou da China, vêm-nos e à Europa os traços mais marcantemente revolucionários em todo o campo social. E a influência estabilizadora, no disciplinamento da inevitável transformação, vem do debate institucionalizado, em círculo nacional de juristas, sob entidade estável e respeitada; impedem-se assim avanços e recuos desencontrados e desagregadores. E o assentimento de legislaturas estaduais aos modelos 
da National Bar Association, observo afinal, apoia-se no fato de a sua National Conference of Commissioners nenhuma violência fazer a grupo algum, antes a todos os Estados pedir apoio e subsídio para o seu trabalho, encontrando estes assim o seu próprio interesse no modelo final, submetido às assembléias legislativas; em outras palavras, no movimento norte-americano das leis-modelos está o cerne da concepção, na Inglaterra defendida por Edward Coke contra James I, a concepção do direito encontrado na própria comunidade, e não imposto por ato de império.

A mesma idéia está presente nas leis da Comunidade Européia, a segunda tentativa de disciplinamento da transformação de sistemas jurídicos, em que me quero apoiar, não para transplante de resultados, mas como exemplo a seguir. O Tratado de Roma estabeleceu como alvo genérico da Comunidade, entre outros, a aproximação das leis dos Estados membros, na medida necessária para o funcionamento adequado do mercado comum; como alvo mais específico, também entre outros, a adoção de normas reguladoras das atividades econômicas e o conseqüente estabelecimento de estatuto comum sobre a concorrência; e como alvo, agora mais precisamente definido, a adoção de uma sociedade anônima européia, de status internacional no âmbito da Comunidade. Quanto ao último destes alvos, dois projetos sucessivos foram já publicados, o primeiro em 1970 e o segundo em 1975, este último sendo ainda considerado, em processo demorado, com o objetivo de chegar a texto apto a obter o assentimento de toda a Comunidade. Também aqui, notem, a idéia fundamental é que o direito não se impõe; as leis, como já se viu no caso norte-americano, só se podem encontrar na comunidade mesma a que se destinam, porque nela reside a soberania p.opular nos Estados-Nações.

Voltemos agora à situação brasileira, reflexo da situação mundial. $O$ disciplinamento da mudança, também aqui imprescindível, só pode vir, a exemplo dos paralelos invocados, de uma aliança de juristas, em entidade fundada com o objetivo declarado de restaurar o prestígio do conceito jurídico rigoroso e do discurso tecnicamente ordenado à luz da lógica. Ora, pela sua longa tradição e pela sua atual influência no mundo jurídico brasileiro, não vejo como possa esta Escola eximir-se da responsabilidade de promover esta aliança, reunindo neste e em todos os demais Estados o talento necessário para canalizar e disciplinar a transformação, que se não poderá impedir, consubstanciando-a afinal em projetos viáveis, a serem aceitos por toda a nação por intermédio de legislatura federal representativa. 
Esta não é todavia a tarefa toda. E preciso também reatar no ensino a linha da boa tradição, formando novos juristas. Ora, se hoje nas escolas de direito a contestação atinge o conceito jurídico e a sua inserção em discurso lógico, esta é a arma a ser usada na luta pela renovação, a exemplo de Coke contra James I, ao usar como arma a concepção jurídica que este impugnava. E é experiência minha nesta Casa, no meu trato com estudantes, que eles reagem negativamente tanto ao argumento ruim como ao argumento bom em tema árido por inatual, mas não ao argumento lógico em tema vital, que este eles sempre acolhem, mesmo que o não saibam usar. A dificuldade está, assim, também no envelhecimento do direito brasileiro e de sua linguagem, que é preciso reformular e refazer, se não quisermos que à míngua de juristas desapareça o direito nacional, e passe o Brasil nesse campo vital a colônia de outra nação.

Não se trata, contudo, de luta sem quartel; não se trata de destruir a nova mentalidade surgida, refazendo-a à imagem e semelhança do jurista de geração anterior. Ao invés, trata-se de levar as novas gerações a compreender e adotar o discurso jurídico escorreito, deixando incólume a riqueza nova que trazem, o seu diferente estilo de vida e as suas diversas personalidades, em todos os seus aspectos - lingüísticos, culturais, artísticos. O novo mundo será diferente, como todo mundo novo, e é bom que o seja, contanto que se preserve entre as gerações a conexão vital da comunicação no campo jurídico, porque a alternativa é a barbárie.

A mais difícil e mais delicada parte de minha tarefa de hoje enfrento afinal - é dizer, embora de modo forçosamente inadequado, da enormidade de minha dívida para com os professores desta Escola, com os quais aprendi, e vou continuar aprendendo, pelo preceito e pelo exemplo, a arte dificílima de pensar na nossa comum disciplina. É confissão que era preciso fazer de público; e a faço aqui, com o protesto de minha grande gratidão.

E agora ao Professor Oscar Barreto Filho o meu agradecimento pela sua grata saudação, que, se defeito tem, está na extrema generosidade e simpatia, generosidade e simpatia que são traços constantes de sua harmoniosa personalidade. 